\title{
Effect of Thermotherapy on the Development of Anthracnose on Post-harvest Mangoes of the Amelie Variety in Côte d'Ivoire
}

\author{
Kouame Koffi Gaston ${ }^{1, ~ *, ~ K a s s i ~ K o f f i ~ F e r n a n d ~ J e a n-m a r t i a l ' ~}{ }^{2}$, Kouame Konan Didier², \\ Kouame Konan", Bolou Bi Bolou Antoine ${ }^{2}$, Kone Daouda ${ }^{2}$ \\ ${ }^{1}$ Biological Sciences Training and Research Unit, Péléforo-Gon-Coulibaly University, Korhogo, Ivory Coast \\ ${ }^{2}$ Faculty of Biosciences; Félix Houphouët Boigny University, Abidjan, Ivory Coast
}

Email address:

k.koffigaston1@yahoo.fr (K. K. Gaston)

${ }^{*}$ Corresponding author

To cite this article:

Kouame Koffi Gaston, Kassi Koffi Fernand Jean-martial, Kouame Konan Didier, Kouame Konan, Bolou Bi Bolou Antoine, Kone Daouda. Effect of Thermotherapy on the Development of Anthracnose on Post-harvest Mangoes of the Amelie Variety in Côte d'Ivoire. American Journal of BioScience. Vol. 9, No. 1, 2021, pp. 17-24. doi: 10.11648/j.ajbio.20210901.13

Received: January 2, 2021; Accepted: January 11, 2021; Published: February 4, 2021

\begin{abstract}
The post-harvest management of anthracnose is a major challenge for the stakeholders in mango sector. This constraint is linked to lake of an effective product and prohibition of several chemical molecules in the post-harvest fruit treatment. The present study aims to evaluate the level of efficiency of hot water in the control of Colletotrichum gloeosporioïdes (Penz), the causal agent of mango anthracnose var. 'Amelie' under in vitro and in vivo test conditions and its effect on some physico-chemical parameters of the fruit. It is part of the research for alternative solutions to the chemical method of controlling mango anthracnose after harvest. The germination inhibitory capacity of $C$. gloeosporioïdes spores of water at $45^{\circ} \mathrm{C}$ and in contact with the fruit during 4 soaking times $(5 ; 10 ; 15$ and $20 \mathrm{~min})$ was evaluated. In addition, the effect of hot water on the development of anthracnose symptoms of artificially inoculated fruits and on their quality was tested. Soaking times of 15 and 20 min effectively reduced $(11.98 \pm 2.72$ and $17.79 \pm 3.18 \%)$ the germination of C. gloeosporioïdes (Penz) spores after 18 hours of observation. Soaking the mangoes in $45^{\circ} \mathrm{C}$ hot water for 20 min showed low infection rates $(22.00 \pm 4.01 \%)$ with small lesion sizes $(0.12 \pm 0.03 \mathrm{~cm})$. However, not all treatments influenced the physico-chemical parameters of the treated var. 'Amélie' mangoes. In sum, hot water at $45^{\circ} \mathrm{C}$ did not provide $100 \%$ protection of the fruits for a long time, but can be used in combination with other methods.
\end{abstract}

Keywords: Thermotherapy, Anthracnose, Post-harvest, Mango, Hot Water

\section{Introduction}

The mango (Mangifera indica L.) is widely cultivated in several tropical and subtropical countries of the world. The world production of this fruit in 2018 amounted to more than 52 million tons [1]. In Côte d'Ivoire, mango production is estimated at more than $100,000 \mathrm{t} / \mathrm{year}$ [2]. It is mainly produced in the North of the country, where it plays a very important socio-economic role. Indeed, it is the third source of income in this part of the country after cashew nuts and cotton. The mango sector provides an annual income of nearly 7 billion CFA francs to more than 7,000 village producers and supports more than 100,000 people in Côte d'Ivoire [3].
However, mango, like other tropical fruits, is subject to attacks from pests and diseases, including anthracnose. This pathology causes significant damage to mango production in all areas where it is grown [4]. It appears at different stages of fruit development, often in the form of black dots on the upper part, close to the peduncle. Symptoms of anthracnose are not noticeable on the fruit during harvest. They are practically undetectable during treatment in packing stations [5]. However, they do become visible on the fruit during ripening. This fact has sometimes led to the rejection of fruit by the European Union market, due to the deterioration of their quality. Because, the quality of fruit is a factor of competitiveness on international markets. The control of 
anthracnose after harvest is an imperative to preserve and improve the quality of mangoes [6]. The traditional method of control using chemical products is increasingly criticized because of the harmful effects of these synthetic products on the environment and consumer health.

One of the current challenges is therefore to find adequate treatments to keep the fruit in good condition; to avoid environmental and ecological problems. In addition, to satisfy consumers, who are increasingly demanding fruit without residues [7].

It is therefore imperative to seek alternative solutions for effective and healthy control for adequate protection of mangoes. Thermotherapy presents itself as one of the best solutions that is environmentally friendly and safe for the consumer. It was one of the first non-chemical control methods studied to reduce the deterioration of fruit quality post-harvest by microorganisms [8]. Hot water treatments of mangoes have several advantages over the use of chemicals to reduce post-harvest decomposition. Indeed, they are easy to implement and short. They do not leave any chemical residue on the surface of the fruit and pathogens can be eradicated even those in the fruit [8]. In addition, they can eliminate quarantine organisms such as fruit flies [9]. In Côte d'Ivoire, the literature mentions very little work on this control method for mango anthracnose.

The present study aims to evaluate the efficacy of hot water in the control of anthracnose of mango var. 'Amelie' in vitro and in vivo, and its effect on some physico-chemical parameters of the fruit.

\section{Materials and Methods}

\subsection{Vegetable and Fungal Material}

The plant material consists of mature, healthy looking mangoes of the 'Amélie' variety. The fruits come from a village farm near the town of Korhogo (Korhogo Wahagninin axis). These fruits were used for the different in vivo control tests. A total of 30 fruits were harvested for each test. The fungal material is an isolate (CA2) of Colletotrichum gloeosporioïdes (Penz). obtained from a mango symptomatic of anthracnose [10].

\subsection{Preparation of the Inoculum}

The pathogen was cultured on PDA medium at $28^{\circ} \mathrm{C}$ with a 12-hour photoperiod for 14 days. Using a curved pasteur pipette, the culture was scraped off in the presence of $10 \mathrm{ml}$ sterile distilled water. The resulting spore suspension was filtered through sterile filter paper No. 4. The suspension was then calibrated using a Malassez cell and adjusted to give a final concentration of $1.5 .10^{4}$ spores $/ \mathrm{ml}$.

\subsection{Effect of Water at $45^{\circ} \mathrm{C}$ on the Germination of Colletotrichum Gloeosporioüdes Spores in Vitro Culture Conditions}

The resulting spore suspension adjusted to $1.5 .10^{4}$ spores $/ \mathrm{ml}$ with sterile distilled water was distributed to five test tubes at $5 \mathrm{ml}$ per tube. Warm water was prepared and maintained at $45^{\circ} \mathrm{C}$ in a water bath. The tubes were then immersed in the water bath for $0 ; 5 ; 10 ; 15$ and 20 min each. The $1 \mathrm{~L}$ agar medium (12 $\mathrm{g}$ agar-agar), prepared by autoclaving at $121^{\circ} \mathrm{C}, 1$ bar for $30 \mathrm{~min}$ was poured into the Petri dishes. Five replicates were carried out simultaneously per treatment. Two parallel lines were drawn at the base of each plate with a marker to facilitate spore counting. $10 \mu \mathrm{l}$ of the spore suspension were spread at each line. Incubation was carried out at $28^{\circ} \mathrm{C}$ for 6 hours. The counts of germinated and ungerminated spores were determined under a light microscope every $6 \mathrm{~h}$. A spore is considered germinated if the length of the germ tube is greater than its smallest diameter [11]. Fifty spores were counted per line, i.e. 100 spores considered for each box. The average spore germination rate for each treatment was then determined.

The efficacy (E) of each treatment was also evaluated according to the following formula [12]:

$$
\mathrm{E}(\%)=[(\mathrm{T} 0-\mathrm{Tc}) / \mathrm{T} 0] \times 100
$$

To $=$ Average rate of spores germinated in the medium control culture

$\mathrm{Tc}=$ Average rate of spores germinated after treatment time c

\subsection{Effect of Hot Water at $45^{\circ} \mathrm{C}$ on the Evolution of Anthracnose Symptoms on Artificially Infected Mangoes}

Mature, healthy looking fruit of the 'Amélie' variety harvested in a village farm near the town of Korhogo. Well the fruits were transported to the laboratory the next day. The fruits were disinfected with soapy water, rinsed three times with tap water, then superficially cleaned with alcohol (70\%), and finally soaked in sterile distilled water. A total of 30 fruits were used for each experiment. The sample was divided into 6 batches of 5 fruits each. Two batches served as controls and 4 for treatment. Using a fine sterile needle, 5 wounds of $4 \mathrm{~mm}$ depth and $0.66 \mathrm{~mm}$ diameter were made on each fruit. Ten microliters of spore suspension (1.5.10 spores $/ \mathrm{ml}$ ) were injected into each wound on the fruits of the 6 lots [13]. One hour after inoculation, the fruits of 4 lots were soaked in water at $45^{\circ} \mathrm{C}$, as follows:

1. the first batch for $5 \mathrm{~min}$;

2. the $2^{\text {nd }}$ batch for $10 \mathrm{~min}$;

3 . the $3^{\text {rd }}$ batch for $15 \mathrm{~min}$;

4. the $4^{\text {th }}$ batch for $20 \mathrm{~min}$.

The $5^{\text {th }}$ batch was inoculated but not treated and serves as a control. Lot 6 was not inoculated or treated. The fruits were put in boxes by treatment and then deposited in a culture room for incubation. Each fruit was previously covered with sterile lotus paper and incubated in the culture room at a temperature of $28^{\circ} \mathrm{C}$ and $70 \%$ relative humidity.

The incubated fruits were observed as early as day 6 after treatment. The number of spots producing lesions as well as the infected fruits were noted. This made it possible to evaluate the infection rate for each treatment. The dimensions 
of each lesion were measured along the two axes of the fruit and the severity of the disease (SM) was assessed for each treatment.

$$
\mathrm{SM}=(\text { Length of lesion }+ \text { Width of lesion }) / 2
$$

Infection rates for each treatment were calculated as follows:

$$
\mathrm{T}(\%)=(\mathrm{Ns} / \mathrm{Nt}) \times 100
$$

T: Injury Rate or Disease Incidence;

Ns: Number of points that produced symptoms;

$\mathrm{N}_{\mathrm{T}}$ : total number of points inoculated

In addition, the efficacy (E) of each treatment on the disease was evaluated according to the formula below [12]:

$$
\mathrm{E}(\%)=[(\mathrm{T} 0-\mathrm{Ti}) / \mathrm{T} 0] \times 100
$$

To $=$ Injury rate (lesion size) for the control.

$\mathrm{Ti}=$ Rate of injury (lesion size) produced on treated fruit.

\subsection{Effect of Hot Water at $45^{\circ} \mathrm{C}$ on Some Physico-chemical Parameters of the Fruit}

The physico-chemical parameters allowing to appreciate the organoleptic qualities of the fruits were evaluated on the $10^{\text {th }}$ day of the experiment. Thus, parameters such as loss of mass, firmness, soluble dry extract, total titratable acidity and $\mathrm{pH}$ were evaluated.

\subsubsection{Loss of Mass}

The mass of the fruits was measured using a Satorius balance with a precision of $0.001 \mathrm{~g}$ before treatment and on the $10^{\text {th }}$ day of the experiment. The measurements made it possible to evaluate the loss of mass of each fruit according to the following formula:

$$
\mathrm{P}_{\mathrm{M}}(\%)=[(\mathrm{A}-\mathrm{B}) / \mathrm{A}] \times 100
$$

P M (\%): mass loss;

A (g): mass of fruit before treatment;

$\mathrm{B}(\mathrm{g})$ : mass of treated fruit on the $10^{\text {th }}$ day.

\subsubsection{Penetrometric Resistance}

The firmness of the whole fruit was measured using a crossbow-type penetrometer. It consisted in evaluating, in Kg. $\mathrm{f}^{-1}$, the resistance to penetration of the cylindrical tip of the instrument ( $8 \mathrm{~mm}$ long, $3 \mathrm{~mm}$ in diameter) inside the fruit. Firmness was measured in 4 points ( 2 on the lateral side, one dorsal and one ventral) and the average of the measurements was calculated for each fruit. Pulp firmness was expressed in kilogram-force.

\subsubsection{Measurement of $\mathrm{pH}$ and Total Titratable Acidity}

The $\mathrm{pH}$ of the pulp juice was measured using a digital handheld $\mathrm{pH}$ meter. For this purpose, $2 \mathrm{~g}$ of pulp from each fruit of the experiment was taken and ground in the presence of $20 \mathrm{ml}$ of distilled water. The ground material was centrifuged at $5000 \mathrm{rpm}$ for $10 \mathrm{~min}$. The supernatant was then collected. A fraction of the supernatant contained in a beaker was used to determine the $\mathrm{pH}$.

The total titratable acidity of the pulp juices, expressed as the content of all the free mineral and organic acids in the different samples was determined by titrimetry using a $0.01 \mathrm{~N}$ sodium hydroxide solution, in the presence of phenolphthalein as a colour indicator [14]. The volumes used made it possible to calculate the total titratable acidity as follows

$$
\mathrm{ATT}=\mathrm{N}_{(\mathrm{NaOH})} \times \mathrm{V}_{\mathrm{NaOH}} / \mathrm{Vs}
$$

ATT: total titratable acidity (in milliequivalents per $10^{2} \mathrm{~g}$ of sample)

$\mathrm{N}$ : title of the sodium hydroxide solution.

$\mathrm{V}_{\mathrm{NaOH}}$ : Volume of $\mathrm{NaOH}$ required for the shade change.

Vs: Total volume of supernatant dosed.

\subsubsection{Soluble and Reducing Carbohydrates}

The total soluble sugar content was determined using a handheld refractometer type Atago Pr-1. The refractive index of the juice expressed in Brix degrees was determined.

The experiment was conducted twice.

\subsection{Statistical Analysis}

The data collected for each test were subjected to an analysis of variance (ANOVA) using Statistica version 7.1 software. Where significant differences were found, the means were compared using the Newman-Keuls test at the 5\% cut-off.

\section{Results}

\subsection{In Vitro Effect of Hot Water $\left(45^{\circ} \mathrm{C}\right)$ on Spore Germination}

The germination rates of $C$. gloeosporioïdes spores and the efficacy of each treatment are shown in Table 1: At the $6^{\text {th }}$ hour of incubation, germination rates of $71.20 \pm 2.06 ; 68.40$ $\pm 1.63 ; 57.20 \pm 1.62$ and $48.80 \pm 1.94 \%$ were induced by treatments T1 (05 min), T2 (10 min), T3 (15 min) and T4 (20 $\mathrm{min})$ respectively. The rate induced by $\mathrm{T} 1$ was statistically identical to that induced by $\mathrm{T} 2$. In addition, the germination rates induced by $\mathrm{T} 3$ and $\mathrm{T} 4$ were significantly different, but similar to the control.

After $12 \mathrm{~h}$ incubation, the T0 $(00 \mathrm{~min}), \mathrm{T} 2(10 \mathrm{~min}), \mathrm{T} 3$ (15 $\mathrm{min})$ and T4 (20 min) treatments resulted in germination rates of $93.90 \pm 2.12 ; 84 \pm 3.39 ; 77 \pm 4.4$ and $76.40 \pm 1.94 \%$ respectively. At the same time, treatments T2, T3 and T4 had similar $(P=0.0539)$ but different $(P=0.0129)$ effect from the control (Table 1). Treatments T2, T3 and T4 induced germination rates of $90.40 \pm 0.51 ; 87.20 \pm 2.06$ and $84.40 \pm$ $1.94 \%$ respectively after $18 \mathrm{~h}$ of spore incubation. These germination rates were significantly different $(P=0.0264)$ from the control (Table 1). Treatments T1 and T2 induced average germination rates of $84.13 \pm 2.70$ and $80.93 \pm 2.73 \%$. These rates were statistically close $(P=0.0747)$ to that of the control (Table 1). The average germination rate obtained with the T4 treatment was $69.87 \pm 4.50 \%$. This rate was 
significantly different from the control, but identical to that of the T3 treatment. The T3 and T4 treatments were the most effective in inhibiting the germination of C. gloeosporioïdes spores. The $\mathrm{T} 1$ treatment accelerated spore germination with an efficiency of $-1.61 \pm 3.82$ (Table 1$)$.

Table 1. Germination rate of Colletotrichum gloeosporioïdes spores soaked in hot water at $45^{\circ} \mathrm{C}$ at different times.

\begin{tabular}{|c|c|c|c|c|c|}
\hline \multirow{2}{*}{ Treatments } & \multicolumn{5}{|c|}{ Spore germination rate $(\%)$} \\
\hline & $6 \mathrm{~h}$ & $12 \mathrm{~h}$ & $18 \mathrm{~h}$ & Medium & Efficiency \\
\hline T0 & $61.80 \pm 4.20 \mathrm{bc}$ & $93.90 \pm 2.12 \mathrm{a}$ & $99.20 \pm 0.49 \mathrm{a}$ & $84.97 \pm 4.65 \mathrm{a}$ & \\
\hline $\mathrm{T} 1$ & $71.20 \pm 2.06 \mathrm{a}$ & $87.60 \pm 2.18 \mathrm{ab}$ & $93.60 \pm 0.81 \mathrm{ab}$ & $84.13 \pm 2.70 \mathrm{a}$ & $-1.61 \pm 3.82 b$ \\
\hline $\mathrm{T} 2$ & $68.40 \pm 1.63 \mathrm{ab}$ & $84 \pm 3.39$ bc & $90.40 \pm 0.51 \mathrm{~b}$ & $80.93 \pm 2.73 \mathrm{a}$ & $2.03 \pm 4.24 \mathrm{~b}$ \\
\hline T 3 & $57.20 \pm 1.62 \mathrm{~b}$ & $77 \pm 4.40 \mathrm{c}$ & $87.20 \pm 2.06 \mathrm{~b}$ & $73.80 \pm 3.69 \mathrm{~b}$ & $11.98 \pm 2.72 \mathrm{a}$ \\
\hline $\mathrm{T} 4$ & $48.80 \pm 1.94 \mathrm{c}$ & $76.40 \pm 1.94 \mathrm{c}$ & $84.40 \pm 1.94 \mathrm{~b}$ & $69.87 \pm 4.50 \mathrm{~b}$ & $17.79 \pm 3.18 \mathrm{a}$ \\
\hline
\end{tabular}

Means in the same column followed by the same letter are statistically identical to the $5 \%$ threshold according to Newman Keuls. $(\mathrm{T} 0=00 \mathrm{~min}$; $\mathrm{T} 1=05 \mathrm{~min}$; $\mathrm{T} 2=10 \mathrm{~min} ; \mathrm{T} 3=15 \mathrm{~min} ; \mathrm{T} 4=20 \mathrm{~min})$

\subsection{Evolution of Anthracnose Symptoms on Artificially Infected Mangoes}

\subsubsection{Action of Hot Water on Disease Incidence}

Lesions characteristic of anthracnose symptoms were observed in fruits treated as controls from the $6^{\text {th }}$ day of incubation. At this date, treatments T0, T1, T2, T3 and T4 induced lesion rates of $10 \pm 5.37 ; 06 \pm 4.27 ; 02 \pm 02 ; 12 \pm$ 6.11 and $06 \pm 4.27 \%$ respectively. These rates were statistically identical $(P=0.0508)$ for all treatments at day 6 . The lesion rate for each treatment increased over time (Figure 1). With the T4 treatment, rates of $12 \pm 8 ; 16 \pm 7.77$; $28 \pm 6.80$ and $34 \pm 7.33 \%$ were recorded on days $7 ; 8 ; 9$ and 10 of the experiment, respectively. These rates were not significantly different $(P=0.153820)$ from those of the T2 and $\mathrm{T} 3$ treatments. With the T0 treatment, the rates of lesions obtained ranged from $24 \pm 7.18 ; 38 \pm 6.96 ; 52 \pm 9.52$ to $60 \pm$ $9.43 \%$ from day 7 to 10 of the experiment (Figure 1).

The incidence of anthracnose on treated mangoes decreased with increasing fruit soaking time (Table 2). Thus, soaking times $\mathrm{T} 3(15 \mathrm{~min})$ and $\mathrm{T} 4(20 \mathrm{~min})$ induced mean rates of $28.40 \pm 3.38$ and $22 \pm 4.01 \%$; whereas, T0 and T1 induced mean rates of $36.8 \pm 4.25$ and $32.40 \pm 3.99 \%$ respectively. These rates were statistically identical $(P=0.05077)$. Treatment efficacy compared with the control was $21.02 \pm$ $15.27,25.83 \pm 9.68,30.35 \pm 10.44$ and $34.16 \pm 11.06 \%$ for treatments T1, T2, T3 and T4, respectively (Table 2).

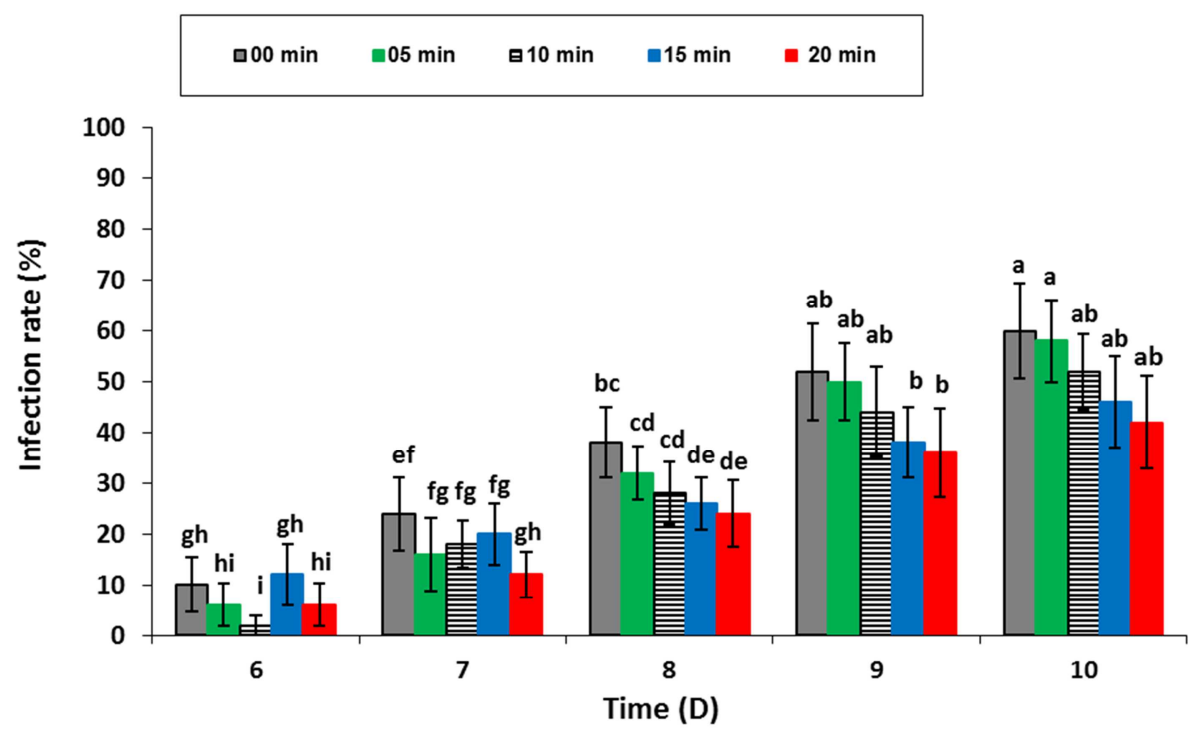

The different letters on the bars indicate significant differences at the $5 \%$ threshold (Newman-Keuls test) between infection rates over time.

Figure 1. Infection rate as a function of time, Amelie' mangoes inoculated with Colletotrichum gloeosporioides and treated with hot water at $45^{\circ} \mathrm{C}$.

Table 2. Incidence and evolution of anthracnose on 'Amelie' mangoes soaked in hot water after inoculation with spores of Colletotrichum gloeosporioïdes.

\begin{tabular}{llll}
\hline Treatments & Average infection rate (\%) & Efficacy (\%) & Lesion size (cm) \\
\hline T0 & $36.80 \pm 4.25 \mathrm{a}$ & & $0.25 \pm 0.04 \mathrm{a}$ \\
T1 & $32.40 \pm 3.99 \mathrm{ab}$ & $21.02 \pm 15.27 \mathrm{a}$ & $0.30 \pm 0.05 \mathrm{a}$ \\
T2 & $28.80 \pm 3.71 \mathrm{ab}$ & $25.83 \pm 9.68 \mathrm{a}$ & $0.24 \pm 0.05 \mathrm{a}$ \\
T3 & $28.40 \pm 3.38 \mathrm{ab}$ & $30.35 \pm 10.44 \mathrm{a}$ & $0.24 \pm 0.04 \mathrm{a}$ \\
T4 & $22.00 \pm 4.01 \mathrm{~b}$ & $34.16 \pm 11.06 \mathrm{a}$ & $0.12 \pm 0.03 \mathrm{~b}$ \\
\hline
\end{tabular}

Means in the same column followed by the same letter are statistically identical to Newman Keuls' $5 \%$ threshold. $(\mathrm{T} 0=00 \mathrm{~min}$; $\mathrm{T} 1=05 \mathrm{~min}$; $\mathrm{T} 2=10 \mathrm{~min}$; $\mathrm{T} 3$ $=15 \mathrm{~min} ; \mathrm{T} 4=20 \mathrm{~min}$ ) 


\subsubsection{Influence of Hot Water on Disease Progression in Mangoes}

The different treatments have more or less reduced the progression of the disease. The size of lesions induced by the treatments ranged from $0.006 \pm 0.006$ to $0.052 \pm 0.032 \mathrm{~cm}$ and from $0.051 \pm 0.018$ to $0.095 \pm 0.035 \mathrm{~cm}$ on days 6 and 7 of the experiment (Figure 2 ). These sizes were statistically close $(P=$ 0.9920). On days 8; 9 and 10 after treatment, the lesion sizes observed in fruits soaked for 20 min were $0.148 \pm 0.041 ; 0.327$ \pm 0.101 and $0.532 \pm 0.132 \mathrm{~cm}$. Conversely, soaking fruits for $05 \mathrm{~min}$ induced lesion sizes that ranged from $0.045 \pm 0.033$ to $0.724 \pm 0.102 \mathrm{~cm}$ throughout the experiment (Figure 2).

The evolution of anthracnose lesions in Amélie mangoes variety was reduced by the soaking time T4 (20 min). This produced lesions with an average size of $0.12 \pm 0.03 \mathrm{~cm}$ (Table 2). Treatment T1 (05 $\mathrm{min})$ induced an average lesion size of $0.30 \pm 0.05 \mathrm{~cm}$, while the average lesion size obtained with the control was $0.25 \pm 0.04 \mathrm{~cm}$ (Table 2).

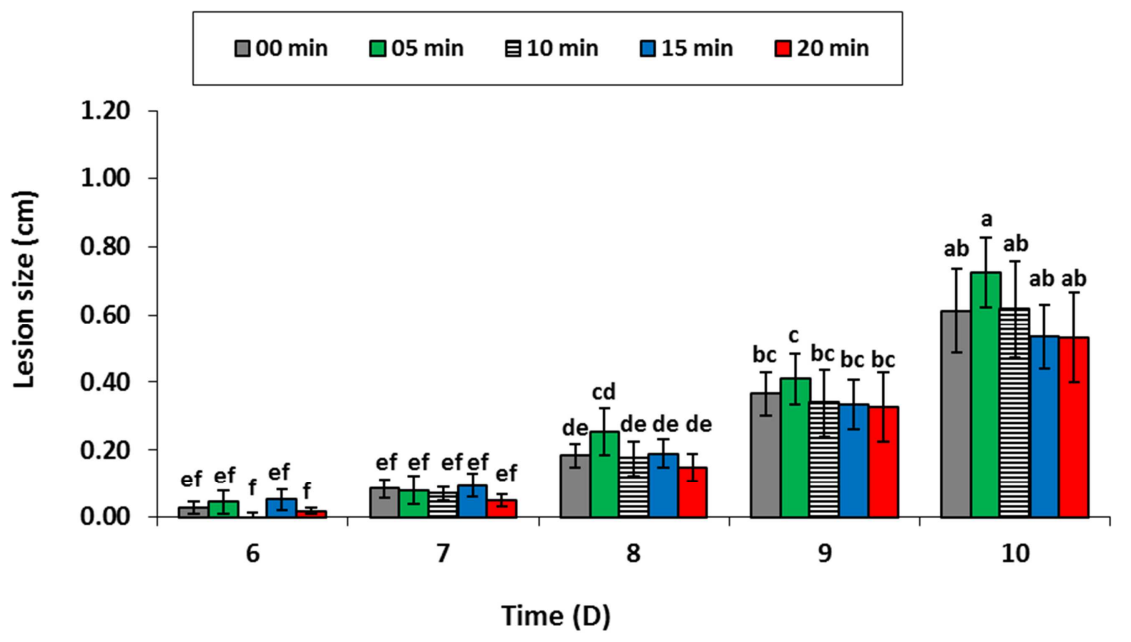

The histogram bars topped with the same letters are not significantly different at the 5\% threshold (Newman-Keuls test).

Figure 2. Size of anthracnose lesions on 'Amelie' mangoes.as a function of time, after inoculation, then treatment with hot water at $45^{\circ} \mathrm{C}$.

\subsection{Effect of Hot Water on Some Physicochemical Parameters of Mangoes of the Amelie Variety}

\subsubsection{Physical Parameters}

The loss of mass, firmness of treated fruits on the $10^{\text {th }}$ day of incubation evaluated are recorded in Table 3. Mass losses of $09.62 \pm 0.27 ; 10.60 \pm 0.35,10.24 \pm 0.38$ and $11.63 \pm 0.67 \%$ were recorded with $\mathrm{T} 0, \mathrm{~T} 2, \mathrm{~T} 3$ and $\mathrm{T} 4$ treatments, respectively. Thus, all soaking times did not cause a significant loss $(P=0.1838)$ in the mass of treated fruit. However, the greatest loss was observed in fruits from the T4 treatment (20 min; Table 3).

Fruit firmness determined for $\mathrm{T} 1$ treatment was $12.06 \pm$ 0.78 and $12.45 \pm 0.68 \mathrm{Kg} . \mathrm{f}^{1}$ for T4. Whereas, the T0 treatment gave a firmness of $13.43 \pm 0.68$ Kg.f $f^{1}$. Fruit firmness was not affected by soaking time $(P=0.0712)$. However, fruits from the T3 treatment showed the highest firmness of $14.41 \pm 1.27 \mathrm{Kg} . \mathrm{f}^{-1}$ (Table 3).

\subsubsection{Chemical Parameters}

The $\mathrm{pH}$ of the juice extracted from the treated fruit was $5.25 \pm 0.12 ; 5.25 \pm 0.10 ; 5.05 \pm 0.10 ; 5.12 \pm 0.19$ and $5.24 \pm$ 0.16 for treatments $\mathrm{T} 0, \mathrm{~T} 1, \mathrm{~T} 2, \mathrm{~T} 3$, and $\mathrm{T} 4$, respectively. Thus, the $\mathrm{pH}$ of these different treatments were statistically identical $(P=0.39644$; Table 3$)$.

As for total soluble sugars, in the fruits of treatments $\mathrm{T} 0$, $\mathrm{T} 1, \mathrm{~T} 3$ and T4, levels of $1.54 \pm 0.04 ; 1.49 \pm 0.04 ; 1.46 \pm 0.07$ and $1.45 \pm 0.05{ }^{\circ}$ Brix were recorded. Soluble sugar levels were not significantly $(P=0.0514)$ influenced by treatments. However, the T4 treatment caused a slight reduction in total soluble sugars (Table 3 ).

The titratable acidity recorded is shown in Table 3 . The table shows that all treatments have identical acidities. The highest value $(2.21 \pm 0.46 \mathrm{mEq} .10-2 \mathrm{~g})$ was obtained with the fruits of the T2 treatment. In contrast, the lowest value $(1.27 \pm 0.13 \mathrm{mEq} .10-2 \mathrm{~g})$ was recorded in the juices from the fruits of the T4 treatment $(20 \mathrm{~min})$.

Table 3. Effect of soaking time in hot water $\left(45^{\circ} \mathrm{C}\right)$ on the physico-chemical parameters of mangoes of the Amélie variety after 10 days of conservation at $28.40 \pm 2^{\circ} \mathrm{C}$.

\begin{tabular}{|c|c|c|c|c|c|}
\hline Treatments & Mass loss (\%) & Firmness $\left(\right.$ Kg.f $\left.^{1}\right)$ & pH & Total soluble sugars ( ${ }^{\circ}$ Brix) & Titratable acidity (mEq.10-2 g) \\
\hline T0 & $09.62 \pm 0.27 \mathrm{a}$ & $13.43 \pm 0.68 \mathrm{a}$ & $5.25 \pm 0.12 \mathrm{a}$ & $1.54 \pm 0.04 \mathrm{a}$ & $1.30 \pm 0.11 \mathrm{a}$ \\
\hline $\mathrm{T} 1$ & $10.14 \pm 0.46 \mathrm{a}$ & $12.06 \pm 0.78 \mathrm{a}$ & $5.25 \pm 0.10 \mathrm{a}$ & $1.49 \pm 0.04 \mathrm{a}$ & $1.53 \pm 0.24 \mathrm{a}$ \\
\hline $\mathrm{T} 2$ & $10.60 \pm 0.35 \mathrm{a}$ & $14.02 \pm 0.98 \mathrm{a}$ & $5.05 \pm 0.19 \mathrm{a}$ & $1.48 \pm 0.06 \mathrm{a}$ & $2.21 \pm 0.46 \mathrm{a}$ \\
\hline T3 & $10.24 \pm 0.38 \mathrm{a}$ & $14.41 \pm 1.27 \mathrm{a}$ & $5.12 \pm 0.19 \mathrm{a}$ & $1.46 \pm 0.07 \mathrm{a}$ & $1.89 \pm 0.27 \mathrm{a}$ \\
\hline $\mathrm{T} 4$ & $11.63 \pm 0.67 \mathrm{a}$ & $12.45 \pm 0.68 \mathrm{a}$ & $5.24 \pm 0.16 \mathrm{a}$ & $1.45 \pm 0.05 \mathrm{a}$ & $1.27 \pm 0.13 \mathrm{a}$ \\
\hline
\end{tabular}

Means in the same column followed by the same letter are statistically identical to the $5 \%$ threshold in the Newman Keuls test. $(\mathrm{T} 0=00 \mathrm{~min}$; $\mathrm{T} 1=05 \mathrm{~min}$; $\mathrm{T} 2$ $=10 \mathrm{~min} ; \mathrm{T} 3=15 \mathrm{~min} ; \mathrm{T} 4=20 \mathrm{~min}$ ) 


\section{Discussion}

Effect of hot water on the incidence and severity of anthracnose

In the present study, the hot water treatments directly influenced the in vitro germination of the treated spores, as well as the development of anthracnose on the mangoes used. The in vitro results indicated that soaking in hot water for 15 and 20 min significantly inhibited the germination of Colletotrichum gloeosporioïdes spores.

Our results are in agreement with those reported by Liu et al [15] on the effect of heat treatment (HT, hot water treatment at $40^{\circ} \mathrm{C}$ for 5 and $10 \mathrm{~min}$ ) against Monilinia fructicola and/or peach brown rot. On the other hand, Mirshekari et al. [16] reported different results from ours during their trials on "Effect of treatment of banana var. Berangan by immersion in hot water against post-harvest anthracnose". Indeed, these authors found that heat treatments (hot water at $50^{\circ} \mathrm{C}$ for 10 and $20 \mathrm{~min}$ ) completely inhibited the germination of Colletotrichum musae spores. In the course of our work, no treatment was able to completely inhibit spore germination. This difference in results can be attributed to the conditions of the experiment. Because, they used a higher temperature than ours, then the observations were made at a lower incubation time $(5,6$ and $7 \mathrm{~h})$. Our results also indicate that with a longer soak time (15 and 20 $\mathrm{min})$, the reduction in spore germination rate is greater.

All this proves that a slightly longer time is needed for the heat to act effectively on the viability of $C$. gloeosporioides spores at a temperature of $45^{\circ} \mathrm{C}$. Previous work has shown that heat treatments directly affect the spores by delaying or totally preventing their germination. They also inhibit the growth of the germ tube. Thus, heat reduces the aggressiveness of the spores and thus minimizes the development of the disease in treated fruit [17]. Our results also show that heat treatments at $45^{\circ} \mathrm{C}$ of Amelie mangoes reduced the incidence and severity of anthracnose caused by C. gloeosporioïdes. Similar results were obtained after treating mangoes with hot water at $52 ; 55$ and $58^{\circ} \mathrm{C}$ for $1 ; 3$ and $5 \mathrm{~min}$ [18]. Similarly, heat treatment protocols developed to treat several varieties of mangoes such as Kent, Keitt, Palmer and Tommy Atkins; mandarins and bananas gave similar results [16, 19-21].

In addition, it indirectly reduces pathogen growth by inducing different resistance mechanisms in the mango pericarp and pulp [15, 21]. In addition, the infection rate as well as the severity of anthracnose increases over time. This indicates that the defense mechanism of the fruits decreases as they ripen [22]. Treatment at $45^{\circ} \mathrm{C}$ for $20 \mathrm{~min}$ of was the most effective; however, it did not completely eliminate the anthracnose.

Influence of hot water on some physico-chemical parameters.

All treatments caused a slight loss of fruit mass with a maximum value corresponding to the longest soaking time compared to that of the controls. These results are close to those of the work of Karabulut et al. [23]. These authors treated table grapes with hot water $\left(30,40\right.$ and $\left.50^{\circ} \mathrm{C}\right)$ and ethanol after harvest. They found that in seedless "Thompson" table grapes, the loss in mass was insignificant and the control had the lowest loss. In contrast, Yousef et al [24] reported that hydro-thermal treatments $\left(48\right.$ or $\left.52^{\circ} \mathrm{C}\right)$ of mangoes for $10 \mathrm{~min}$ and stored at low temperature resulted in a small loss of mass compared to the control on the $14^{\text {th }}$ day of storage. The discrepancy in the results can be attributed to the different temperatures used in these studies. In addition, after the treatments, in our study, the fruits were incubated at room temperature, whereas in these authors, the fruits were stored at low temperature at $10^{\circ} \mathrm{C}$.

The firmness of the fruits was not influenced by the different treatments. This shows that hot water at $45^{\circ} \mathrm{C}$ did not favour or inhibit the activity of the fruit softening factors. In fact, the loss of firmness would result from the hydrolysis and degradation of the pectic components of the cell wall by enzymes such as polygalacturonases (PG), B-galactosidase (b-gal) and pectin methylesterase [25, 26]. Our results are consistent with those of the work of Gutierrez-Martínez et al. [27] on the influence of ethanol and heat on the disease and quality of mangoes var. "Tommy Atkins" in conservation. They reported that the firmness of the treated fruits and that of the controls were similar.

For total soluble sugars, the treatments did not cause considerable variation. This clearly shows that the hot water tested had no effect on the ripening of Amelie mangoes. These observations are consistent with those reported by Le et al [18]. They noted that the sugar levels of mangoes treated with hot water $\left(55^{\circ} \mathrm{C}\right.$ at $\left.3 \mathrm{~min}\right)$ and steam $\left(46^{\circ} \mathrm{C}\right.$ at 40 min) did not vary significantly during the 3 weeks of storage. Anwar and Malik [28] found opposite results when they treated the mangoes with hot water $\left(45^{\circ} \mathrm{C}\right.$ or $\left.48^{\circ} \mathrm{C}\right)$ for 75 or $60 \mathrm{~min}$. Indeed, they reported that the treatments had a significant effect on soluble sugar levels.

The titratable acidity of the fruit subjected to the different treatments was not really influenced [29]. However, the highest value was obtained with soaking at $10 \mathrm{~min}$, while the lowest acidity was obtained with the longest soaking time. These results indicate that the more mangoes (var governor) are exposed to heat, they produce less acid. Djioua et al. [29] made similar observations on Keitt mangoes soaked in hot water maintained at 46 or $50^{\circ} \mathrm{C}$ for 30 or $75 \mathrm{~min}$.

Furthermore, the $\mathrm{pH}$ of the fruits was not affected by the different treatments [30]. This result reinforces that of titratable acidity. The $\mathrm{pH}$ of the treatments that gave low acidity levels was higher. The $\mathrm{pH}$ and titratable acidity increase in opposite directions [20].

\section{Conclusion}

At the end of our analysis, it appears that soaking in hot water $\left(45^{\circ} \mathrm{C}\right)$ for $20 \mathrm{~min}$ inhibits germination and vitality of C. gloeosporioides spores. Thus, the virulence of the pathogen was reduced. The treated fruits showed the 
anthracnose disease a little later. This method did not provide $100 \%$ protection of the fruits for a long time. It did, however, completely delay the onset of anthracnose symptoms for the first 6 days in the treated fruit. In addition, the hot water did not alter the physico-chemical parameters of the treated fruits.

\section{References}

[1] FAO (Food and Agriculture Organization). 2020. Principaux fruits tropicaux - Compendium Statistique 2018. Rome. 31p

[2] FIRCA (Fonds Interprofessionnel pour la Recherché et le Conseil Agricole) 2014. Filière du progress: Actes 13 "Les filières fruitières", Bulletin d'information $\mathrm{du}$ Fonds Interprofessionnel pour la recherché et le conseil agricole; pp 4-9

[3] FIRCA (Fonds Interprofessionnel pour la Recherché et le Conseil Agricole). 2018, la maison des filières agricoles, Rapport Annuel 2018, 61p.

[4] Akem C. N. 2006. Mango anthracnose disease: present status and future research priorities. Plant Pathology Journal 5 (3): 266-273.

[5] Moulin A. 2008. Mangue d'Afrique de l'Ouest. «Perspectives pour la campagne 2008». Les dossiers de Fruitrop, $\mathrm{N}^{\circ} 153$, Février 2008: 26-30.

[6] Korsten L. 2006. Advances in control of postharvest diseases in tropical fresh produce. Int. J. Postharvest Technology and Innovation. 1(1): 48-61.

[7] Conway W. S., Leverentz B. Janisiewicz W. J., Blodgett A. B., Saftner R. A. and Camp M. J. 2004. Integrating heat treatment, biocontrol and sodium bicarbonate to reduce postharvest decay of apple caused by Colletotrichum acutatum and Penicillium expansum Postharvest Biology and Technology, 34 (1): 11-20.

[8] Janisiewicz W. J. et Conway W. S. 2010. Combining biological control with physical and chemical treatments to control fruit decay after harvest, Stewart Postharvest Review 2010, 1: 3 doi: 10.2212/spr.2010.1.3.

[9] Renar J. B., Seibert E. et Jeffrey K. B. 2003. Heat treatment effects on ACC oxidase activity of 'Keitt' mangoes; Braz. J. Plant Physiol., 15 (3): 145-148.

[10] Kouamé K. G. Abo K., Dick E., Bomisso E. L., Koné D., Aké S. and Yatty J. 2010. Artificial wounds implication for the development of mango (Mangifera Indica L. Anacardiaceae) fruit disease caused by Colletotrichum gloeosporiö̈des (Penz.) Sacc. (Glomerellaceae). Int. J. Biol. Chem. Sci. 4 (5): 16211628.

[11] Mlaiki A. (1970). Pourriture à Gleosporium des pommes "Golden Delicious" au cours de leur conservation. Annales INRAT; 43:15-27

[12] Mokhtar H. and Dehimat A. 2014. In vitro and in vivo efficiency of Trichoderma harzianum against Rhizopus soft rot occurred on tomato fruits (Lycopersicon esculentum). Agriculture and biology journal of North America, 5 (6): 240244.

[13] Kouamé K. G., Kouassi K. N., Kassi F. M., Bolou Bi B. A,
Tuo S., Kanko C. and Koné D. 2015 Antifungal Activity of Essential Oils Extracted from Monodora myristica (Gaertn), Ocimum gratissimum L. and Zingiber officinalis Roscoe on Post-harvest Anthracnose of Mango Fruit (Mangifera indica L.) Variety Kent in Côte d'Ivoire. International Journal of Sciences 4 (12): 8-18.

[14] Ezoua P, Kouamé D, Agbo NG. 1999. Caractéristique du jus de la pulpe fraîche du fruit de rônier (Borassus aethiopum Mart). Cahiers Agr., 8: 126-128.

[15] Liu J., Sui Y., Wisniewski M., Drobyc S., Tianb S., Norelli J and Hershkovitzc V. 2012. Effect of heat treatment on inhibition of Monilinia fructicola and induction of disease resistance in peach fruit. Postharvest Biology and Technology 65: 61-68.

[16] Mirshekari A., Ding P., Kadir J. and Ghazali H. M. (2012). Effect of hot water dip treatment on postharvest anthracnose of banana var. Berangan. African Journal of Agricultural Research 7 (1): 6-10.

[17] Schirra M., D'Hallewin G., Ben-Yehoshua S. and Fallik E. 2000. Host-pathogen interactions modulated by heat treatment. Postharvest Biology and Technology 21 (1): 71-85.

[18] Le T. N., Shiesh C. C and Lin H. L. 2010. Effect of vapor heat and hot water treatments on disease incidence and quality of Taiwan native strain mango fruits. International Journal of Agriculture and Biology 12: 673-678.

[19] Mansour F. S. Abd-El-Aziz, S. A and Helal G. A. 2006. Effect of fruit heat treatment in three mango varieties on incidence of postharvest fungal disease. Journal of Plant Pathology 88 (2): 141-148.

[20] Kumah P., Appiah F. and Opoku-Debrah J. K. 2011. Effect of hot water treatment on quality and shelf-life of Keitt mango. Agriculture and Biology Journal of North America. 2 (5): 806 $-817$.

[21] Inkha S. and Boonyakiat D. 2010. Induction of resistance to Penicillium digitatum in tangerine fruit cv. Sai Num Phung flavedo by hot water treatment. Songklanakarin Journal of Science and Technology 32 (5): 445-451.

[22] Jinyoung L., Tae H. L and Byeongjin C. 2002. Isolation and identification of Colletotrichum musae from imported bananas. Plant Pathology Journal 18 (3): 161-164.

[23] Karabulut O. A., Gabler F. M., Mansour M. and Smilanick J. L. 2004. Postharvest ethanol and hot water treatments of table grapes to control gray mold. Postharvest Biology and Technology. 34: 169-177.

[24] Yousef A. R. M., Emam H. S. and Ahmed D. M. M. 2012. Storage and Hot Water Treatments on Poststorage Quality of Mango Fruit (Mangifera indica L.) Variety Copania. Australian journal of Basic \& Applied Sciences 6 (13): 490496.

[25] Ali Z. M., Chin L. H. and Lazan H. A. 2004. Comparative study on wall degrading enzymes, pectin modifications and softening during ripening of selected tropical fruits. Plant Sciences. 167 (2): 317-327.

[26] Zhang Z., Zhaoyin G., Li Min, Hu Meijiao, Gao Hui, Yang D. and Yang Bo. 2012. Hot Water Treatment Maintains Normal Ripening and Cell Wall Metabolism in Mango (Mangifera indica L.) Fruit. Hortscience, 47 (10): 1466-1471. 
[27] Gutiérrez-Martínez, P., Osuna-López, S. G., Calderón-Santoyo, M., Cruz-Hernández, A. and Bautista-Baños, S. 2012. Influence of ethanol and heat on disease control and quality in stored mango fruits. LWT - Food Science and Technology 45: $20-27$

[28] Anwar R. and Malik A. U. 2007. Hot water treatment affects ripening quality and storage life of mango (mangifera indica L.). Pakistan Journal of Agricultural Sciences 44 (2): 304-311.
[29] Jacobi K. K., MacRae E. A. and Hetherington S. E. 2000. Effects of hot air conditioning of 'Kensington' mango fruit on the response to hot water treatment. Postharvest Biology and Technology 21: 39-49.

[30] Djioua T., Charles F., Lopez-Lauri F., Filgueirasb H., Coudreta A., Freire Jrc M., Ducamp- Collind M. N. and Sallanon H. 2009. Improving the storage of minimally processed mangoes (Mangifera indica L.) by hot water treatments. Postharvest Biology and Technology 52: 221-226. 